\title{
Optimum Dietary Standardized lleal Digestible Isoleucine to Lysine Ratio for Meat-Type Quails in the Growing-Finishing Phase
}

-Author(s)
Viana GS'
Barreto SLT'
Muniz JCL'
Arnaut PR'
Santana LC"
Alves WJ"'
Hannas MI'
Tizziani T'
' Universidade Federal de Viçosa, Viçosa,
Minas Gerais, Brasil
" Instituto Federal Sudeste de Minas, Rio
Pomba, Minas Gerais, Brasil
"II Universidade Estadual Paulista Júlio de
Mesquita Filho, Jaboticabal, São Paulo,
Brasil

\section{Mail Address}

Corresponding author e-mail address Gabriel da Silva Viana

Avenida Bruno Martinho, n 145, ap. 103, CEP. 36570-000. Viçosa, MG, Brazil.

Tel: $\quad$ (31) 975647394

Email: mail.gsviana@gmail.com

\section{-Keywords}

Branched-chain amino acids, Coturnix coturnix coturnix, ideal protein.

\section{ABSTRACT}

This study was conducted to determine the optimum standardized ileal digestible isoleucine to lysine (SID Ile:Lys) ratio for meat-type quails from 15 to $35 \mathrm{~d}$ of age. Three hundred fifty not-sexed meattype quails (Coturnix coturnix coturnix) were randomly assigned into five treatments, with seven replicates of 10 quails each. An isoleucinedeficient corn-soybean meal-based diet was formulated and graded supplemented with L-isoleucine (99\%) to obtain diets containing SID Ile:Lys ratios of $55,61,67,73$, and $79 \%$. Data were analyzed as oneway ANOVA and optimum SID lle:Lys was estimated by polynomial (linear and quadratic) regression. Statistical differences were considered when $p<0.05$. Quail performance from 15 and $21 d$ and 15 and $28 d$ of age was not affected by the treatments. From 15 to $35 \mathrm{~d}$ of age, body weight gain and body weight exhibited a quadratic response to increasing dietary SID lle:Lys ratios, and were optimized at 66 and $67 \%$ SID lle:Lys, respectively. Feed conversion ratio was not influenced by SID Ile:Lys ratios in any of the phases assessed herein. Based on the results, the optimum SID lle:Lys ratio for meat-type quails from 15 to $35 \mathrm{~d}$ of age is $67 \%$.

\section{INTRODUCTION}

The branched-chain amino acids (BCAA) valine (Val), isoleucine (Ile), and leucine (Leu) play an important role on poultry growth, since together they account for $35 \%$ of muscle proteins. Due to similarities in their molecular structure, branched-chain amino acids share common intestinal transport systems through the enterocyte membranes and are broken down by the same enzymes (Harper, 1984; Broer, 2008). Langer et al. (2000) demonstrated that alpha-ketoisocaproate, the $\alpha$-keto acid derived from leucine transamination, enhances the activity of the branched-chain $\alpha$-keto acids dehydrogenase complex $(B C K D H)$, resulting in valine and isoleucine catabolism in the liver of pigs.

Isoleucine is reported as the fifth limiting amino acid in diets based on corn and soybean meal, and as the fourth limiting amino acid in broiler diets containing $3 \%$ or more protein from animal by-product sources (Corzo et al., 2010). Literature data suggest that the SID Ile:Lys ratio for optimal broiler performance during the growing-finishing phase ranges between 67\% (Baker et al., 1994; Kidd et al., 2004) and 68\% (Rostagno et al., 2011). Unlike broilers, the nutritional requirements of meat-type quail are not completely defined yet. Silva \& Costa (2009) propose a $84 \%$ SID Ile:Lys ratio for optimum meat-type quail growth, whereas Batista, (2013) estimated an ideal SID Ile:Lys ratio of $46 \%$ for growing-finishing meat-type quails.

The supplementation of commercial poultry diets with crystalline amino acids (e.g. L-Lys, DL-Met, and L-Thr) has allowed reducing feed costs and nitrogen excretion, without compromising production 
Viana GS, Barreto SLT, Muniz JCL, Arnaut PR, Santana LC, Alves WJ, Hannas M, Tizziani T
Optimum Dietary Standardized Ileal Digestible Isoleucine to Lysine Ratio for Meat-Type Quails in the Growing-Finishing Phase per-formance. Nevertheless, the application of such approach requires previous knowledge of bird amino acid requirement to avoid insufficient dietary supply. Considering a practical scenario, in which low-protein diets containing animal protein meal are generally used to reduce feed costs, discrepancies about optimum SID Ile:Lys ratio for meat-type quails may limit the application of such nutritional strategy. Therefore, this experiment was conducted to determine the ideal SID lle:Lys ratio requirements for the optimal performance of meat-type quails form 15 to $35 \mathrm{~d}$ of age.

\section{MATERIALS AND METHODS}

\section{Animal care and use}

The experimental procedures involving animal care and use were previously approved by the institutional Animal Care and Use Committee of the Federal University of Viçosa, Viçosa, Minas Gerais, Brazil.

\section{Bird husbandry and experimental design}

From one to $14 \mathrm{~d}$ of age, meat-type quails were housed in a controlled-temperature room with concrete floor covered with wood-shavings litter. Diets (mash form) were formulated to Silva \& Costa (2009). At $15 \mathrm{~d}$ of age, a total of 350 notsexed quails were housed in a double-curtain sided room, and were randomly allotted to one of five treatments, with seven replicates of 10 birds each. The experimental unit consisted of a $50 \times 50 \times 30$ $\mathrm{cm}$ metal cage, equipped with one nipple drinker and one stainless steel self-feeder, with 10 quails each. Diets and water were supplied ad libitum throughout the trial. Environmental temperature and humidity were daily measured. Light was supplied 24 hours a day (natural + artificial).

\section{Diets}

The experimental diets (Table 1) were formulated to meet or exceed the nutritional requirements recommended by Silva \& Costa (2009), except for digestible amino acids requirements. In order to establish the ideal amino acid profile for meat-type quails, previous experiments were conducted to determine SID Met:Lys, SID Thr:Lys, and SID Trp:Lys ratios for optimal meat-type quail performance. Therefore, the basal diet of the current trial was formulated to contain the SID Met:Lys, SID Thr:Lys, and SID Trp:Lys ratios recommended by Ribeiro (2015) and the SID Val:Lys ratio according to Alves et al. (2016).
Table 1 - Ingredients and calculated nutritional composition of the experimental diets.

\begin{tabular}{|c|c|}
\hline Ingredients & Amount $(\mathrm{g} / \mathrm{kg})$ \\
\hline Corn $(7.88 \%)$ & 724.10 \\
\hline Soybean meal (45.22\%) & 227.70 \\
\hline Soybean oil & 1.14 \\
\hline Limestone & 9.29 \\
\hline Dicalcium phosphate & 11.16 \\
\hline Salt & 3.30 \\
\hline L-Lysine $\mathrm{HCl}(78.9 \%)$ & 4.91 \\
\hline DL-Methionine (99\%) & 4.69 \\
\hline L-Threonine (98.5\%) & 2.84 \\
\hline L-Tryptophan (99\%) & 0.32 \\
\hline L-Valine (96.5\%) & 1.86 \\
\hline L-Isoleucine (99\%) & - \\
\hline Cornstarch & 5.00 \\
\hline Mineral premix ${ }^{1}$ & 1.00 \\
\hline Vitamin premix ${ }^{2}$ & 1.00 \\
\hline Choline chloride (60\%) & 0.100 \\
\hline Antioxidant ${ }^{3}$ & 0.10 \\
\hline Coccidiostat $^{4}$ & 0.50 \\
\hline Antibiotic ${ }^{5}$ & 0.10 \\
\hline \multicolumn{2}{|l|}{ Calculated composition } \\
\hline Metabolizable energy (kcal/kg) & 3,050 \\
\hline Crude protein $(\mathrm{g} / \mathrm{kg})$ & 171.0 \\
\hline Calcium $(\mathrm{g} / \mathrm{kg})$ & 7.00 \\
\hline Available phosphorous (g/kg) & 3.00 \\
\hline Sodium (g/kg) & 1.50 \\
\hline SID Lysine $(\mathrm{g} / \mathrm{kg})$ & 11.10 \\
\hline SID Methionine + Cysteine (g/kg) & 9.32 \\
\hline SID Threonine (g/kg) & 8.33 \\
\hline SID Tryptophan (g/kg) & 2.00 \\
\hline SID Valine $(\mathrm{g} / \mathrm{kg})$ & 8.66 \\
\hline SID Isoleucine (g/kg) & 6.11 \\
\hline SID Leucine $(\mathrm{g} / \mathrm{kg})$ & 14.00 \\
\hline
\end{tabular}

'Mineral premix (amount per kg diet): Manganese 160g. Iron 100g. Zinc 100g. Copper 20g. Cobalt: 2g. Iodine: 2 g. excipient: $616 \mathrm{~g}$. ${ }^{2}$ Vitamin premix (amount per kg diet): Vit. A: 12,000,000 IU, Vit D3: 3.600 .000 IU, Vit. E: 3,500 IU, Vit B1: 2,500 mg, Vit B2: 8,000 mg, Vit B6: 5,000 mg, Pantothenic acid: 12,000 mg, Biotin: 200 mg, Vit. K: 3,000 mg, Folic acid: 1,500mg, Nicotinic acid: $40,000 \mathrm{mg}$, Vit. B12: 20,000 mg, Selenium: $150 \mathrm{mg}$. Excipient qsp. ${ }^{3}$ Butil-hidroxy-toluen. ${ }^{4}$ Salinomycin $60 \% .{ }^{5}$ Avilamycin.

The basal diet was formulated to contain $90 \%$ SID Lys $(11.10 \mathrm{~g} / \mathrm{kg})$, as recommended by Silva \& Costa (2009). The ingredient and nutritional composition values used for diet formulation were those described by Rostagno et al. (2011). Crystalline L-lle was supplemented at graded levels $(0.000,0.067,0.134$, 0.201 , and 0.269), in replacement of cornstarch in the isoleucine-deficient basal diet to obtain the experimental treatments, which consisted of five SID lle:Lys ratios $(55,61,67,73$, and 79\%).

\section{Performance parameters}

At 21, 28 and $35 \mathrm{~d}$ of age, quails and feeders were weighed to determine body weight and feed intake during each phase. Feed intake was divided by weight 
Viana GS, Barreto SLT, Muniz JCL, Arnaut PR, Santana LC, Alves WJ, Hannas M, Tizziani T
Optimum Dietary Standardized Ileal Digestible Isoleucine to Lysine Ratio for Meat-Type Quails in the Growing-Finishing Phase gain to obtain the feed conversion ratio. Mortality was daily recorded to adjust feed intake and feed conversion ratio.

\section{Statistical analysis}

Data were analyzed as one-way ANOVA and the ideal dietary SID lle:Lys ratio was estimated by polynomial (linear and quadratic) regression analyses. Statistical analyses were performed using the software package Sistemas de Análises Estatísticas e Genéticas (SAEG, 2007). SID lle:Lys ratio effects were considered significant when $p<0.05$.

\section{RESULTS}

The effects of dietary SID lle:Lys ratios on on meattype quail performance are presented in Tables 2, 3 and 4. Live performance from 15 to $21 \mathrm{~d}$ and 15 to $28 \mathrm{~d}$ of age (Tables 2 and 3 ) was not influenced ( $p>0.05$ ) by the evaluated dietary SID Ile:Lys ratios. However, from 15 to $35 \mathrm{~d}$ of age (Table 4), body weight gain and body weight were optimized at 66 and $67 \%$ SID lle:Lys ratios, respectively, according to quadratic regression model $(p<0.05)$. Feed conversion ratio was not influenced by the treatments, regardless of rearing phase.

Table 2 - Performance of meat-type quails fed different SID lle:Lys ratios from 15 to $21 \mathrm{~d}$ of age.

\begin{tabular}{lcccc}
\hline SID Ile:Lys (\%) & $\mathrm{Fl}(\mathrm{g})$ & WG $(\mathrm{g})$ & $\mathrm{FCR}(\mathrm{kg} / \mathrm{kg})$ & $\mathrm{BW}(\mathrm{g})$ \\
\hline 55 & 103.48 & 45.43 & 2.28 & 133.11 \\
61 & 104.14 & 45.33 & 2.30 & 133.21 \\
67 & 104.82 & 45.08 & 2.23 & 134.88 \\
73 & 102.88 & 46.00 & 2.24 & 133.88 \\
79 & 104.26 & 46.00 & 2.27 & 133.93 \\
CV $(\%)$ & 1.85 & 3.11 & 2.30 & 1.08 \\
P-Value & & & & \\
Linear & 0.999 & 0.297 & 0.184 & 0.192 \\
Quadratic & 0.999 & 0.201 & 0.167 & 0.182 \\
\hline
\end{tabular}

${ }^{1}$ Coefficient of variation

Feed intake (FI), body weight gain (WG), feed conversion ratio (FCR), body weight (BW)

Table 3 - Performance of meat-type quails fed different SID lle:Lys ratios from 15 to $28 \mathrm{~d}$ of age.

\begin{tabular}{lcccc}
\hline SID lle:Lys (\%) & $\mathrm{Fl}(\mathrm{g})$ & WG $(\mathrm{g})$ & $\mathrm{FCR}(\mathrm{kg} / \mathrm{kg})$ & $\mathrm{BW}(\mathrm{g})$ \\
\hline 55 & 240.43 & 90.81 & 2.65 & 178.49 \\
61 & 242.33 & 91.14 & 2.66 & 179.02 \\
67 & 244.85 & 93.64 & 2.62 & 181.59 \\
73 & 243.21 & 92.31 & 2.63 & 180.20 \\
79 & 241.40 & 91.51 & 2.64 & 179.44 \\
CV $^{1}(\%)$ & 2.18 & 3.77 & 2.35 & 1.92 \\
P-Value & & & & \\
Linear & 0.999 & 0.999 & 0.999 & 0.999 \\
Quadratic & 0.132 & 0.222 & 0.999 & 0.206 \\
\hline
\end{tabular}

${ }^{1}$ Coefficient of variation

Feed intake (FI), body weight gain (WG), feed conversion ratio (FCR), body weight (BW)
Table 4 - Performance of meat-type quails fed different SID lle:Lys ratios from 15 to $35 \mathrm{~d}$ of age.

\begin{tabular}{lllll}
\hline SID Ile:Lys (\%) & Fl (g) & WG $(\mathrm{g})$ & FCR $(\mathrm{kg} / \mathrm{kg})$ & $\mathrm{BW}(\mathrm{g})$ \\
\hline 55 & 425.22 & 136.52 & 3.11 & 224.21 \\
61 & 427.98 & 139.47 & 3.07 & 227.35 \\
67 & 434.36 & 141.78 & 3.06 & 229.58 \\
73 & 426.86 & 137.82 & 3.10 & 225.70 \\
79 & 426.07 & 136.04 & 3.13 & 223.97 \\
$\mathrm{CV}^{1}(\%)$ & 2.78 & 3.69 & 2.68 & 2.38 \\
P-Value & & & & \\
Linear & 0.999 & 0.999 & 0.999 & 0.999 \\
Quadratic & 0.222 & 0.037 & 0.101 & 0.045 \\
\hline
\end{tabular}

${ }^{1}$ Coefficient of variation

Feed intake (FI), body weight gain (WG), feed conversion ratio (FCR), body weight (BW)

\section{DISCUSSION}

As shown in Table 5, dietary SID lle:Lys ratios of 66 and $67 \%$ optimized quails' body weight gain and body weight from 15 to $35 \mathrm{~d}$ of age. Campos et al. (2012) determined a $72 \%$ SID lle:Lys ratio for optimal weight gain of 28- to 40-d-old broilers. Similarly, Duarte (2015) recommended an optimum SID lle:Lys ratio for broiler in the growing-finishing phase at $72 \%$.

Table 5 - Regression equations of performance parameters of meat-type quails fed different SID Ile:Lys ratios between 15 and 35 days of age.

\begin{tabular}{llcc}
\hline Variable & Regression Equation & Estimate & $R^{2}$ \\
\hline WG & $3.3845+4.1387 x-0,0312 x^{2}$ & 66.33 & 0.83 \\
BW & $89.633+4.1786 x-0.0314 x^{2}$ & 66.53 & 0.84 \\
\hline
\end{tabular}

Weight gain (WG) and body weight (BW)

The SID Ile:Lys ratio requirement for optimal meattype quail performance determined in the present study is different from the values published in literature. Batista (2013) suggested that the SID Ile:Lys ratio optimum meat-type quail growth was lower than $48 \%$, whereas Silva \& Costa (2009) recommend a SID lle:Lys ratio of $84 \%$. However, the SID lle:Lys ratio herein determined is close to that recommended by Rostagno et al. (2011) for growing-finishing broilers (68\%).

Branched-chain amino acids share common transport systems through the enterocyte membranes and are broken down by the same enzymes (Harper, 1984). Studies have shown that low Val and Leu concentrations increase lle blood levels in laying hens, which are reduced when both amino acids are supplied at high concentrations in the diet (Peganova \& Eder, 2003). The dietary SID Val:Lys ratios supplied in the current study were previously determined in quails of the same age. Therefore, it is unlikely that Val influenced lle metabolism. Nevertheless, the same 
Viana GS, Barreto SLT, Muniz JCL, Arnaut PR, Santana LC, Alves WJ, Hannas M, Tizziani T

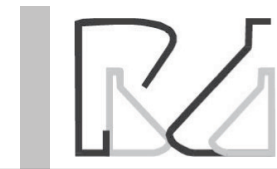

inference on the effects of the Leu content in the basal diet on lle metabolism cannot be made.

There are no data in literature on ideal SID Leu:Lys ratios for meat-type quails. However, considering the similarity of the SID lle:Lys ratios herein estimated for meat-type quail with those recommended by Rostagno et al. (2011) for broilers, it is possible that the SID Leu:Lys ratios present the same behavior in both species. The SID Leu:Lys ratio in the basal diet was $126 \%$, which is higher than the 108\% described by Rostagno et al. (2011) for optimal broiler growth. Taking into account the antagonism among BCAA mentioned above, the Leu content of the basal diet may explain the poorer performance of quails fed diets containing lower SID lle:Lys ratios.

The margin between lle requirement and excess is very narrow in laying hens (Peganova \& Eder, 2002). Peganova \& Eder (2003) reported that increasing dietary lle supply from 8.0 to $10.0 \mathrm{~g} / \mathrm{kg}$ reduced layers' feed intake and egg mass (Peganova \& Eder, 2002). However, such detrimental effect of excessive dietary lle levels appears not to be related with the competition between Val and Leu for intestinal absorption. Peganova \& Eder (2003) did not observe any deleterious effects of excessive lle supply on Val and Leu blood levels in laying hens. However, those authors reported that, at high dietary levels, lle reduced Lys blood concentration. Such negative interaction may explain the body weight gain and body weight reduction observed when dietary SID lle:Lys ratio increased from 67 to $73 \%$ and to $79 \%$ respectively, considering that Lys is almost totally used for body protein accretion (Hamid et al., 2015).

Based on the results obtained in the present study, it is concluded that the SID lle:Lys ratio for meat-type quails from 15 to $35 \mathrm{~d}$ of age is $67 \%$.

\section{REFERENCES}

Alves WJ, Viana GS, Barreto SLT, Muniz JCL, Hannas MI, et al. Optimum digestible valine to lysine ratio for meat-type quails from 15 to $35 \mathrm{~d}$ of age. Ciência Avícola. In press 2016.

Baker DH, Han Y. Ideal amino acid profile for chicks during the first few weeks post-hatching. Poultry Science 1994;73:1441-1447.

Batista E. Exigência de lisina, arginina, valina e isoleucina digestível para codornas de corte [tese]. Maringá (PR): Universidade Estadual de Maringá; 2013.
Optimum Dietary Standardized Ileal Digestible

Isoleucine to Lysine Ratio for Meat-Type Quails in the Growing-Finishing Phase

Broer S. Amino acid transport across mammalian intestinal and rena epithelia. Physiological Reviews 2008;88:249-286.

Campos AMA, Rostagno HS, Nogueira ET, Albino LFT, Pereirall JPL, Maia RC. Atualização da proteína ideal para frangos de corte: arginina, isoleucina, valina e triptofano. Revista Brasileira de Zootecnia 2012;41:326-332.

Corzo A, Dozier WA, Loar RE, Kidd MT, Tillman PB. Dietary limitation of isoleucine and valine in diets based of maize, soybean meal, and meat-and-bone meal for broiler chickens. British Poultry Science 2010;51:558-563.

Dozier WA, Corzo A, Kidd MT. Determination of the fourth and fifth limiting amino acids in broilers fed on diets containing maize, soybean meal and poultry by-product meal from 28 to $42 \mathrm{~d}$ of age. British Poultry Science 2011;52:238-244.

Duarte KF, Junqueira OM, Filardi RS, Laurentiz AC, Domingues CHF, Rodrigues EA. Digestible isoleucine requirements for 22- and 42-dayold broilers. Acta Scientiarum 2015;37:23-28.

Hamid SNIN, Yusof SJHM, Zacaaria Z, Abdullah R. Evaluation of potential alternative ingredients for formulation of fish feed. Applied Mechanics and Materials 2015;754:1081-1086.

Harper AE. Interrelationships among the branched chain amino acids. In: Adibi SA, Fekl W, Langenbeck U, Schauder P, editors. Branched chain amino and keto acids in health and disease. Proceedings of the International Symposium; 1983 Oct; Göttingen. Basel: Karger;1984. p.81-99

Kidd MT, Burnham DJ, Kerr BJ. Dietary isoleucine responses in broiler chickens. British Poultry Science 2004;45:67-75

Langer S, Scislowski PWD, Brown DS, Dewey P, Fuller MF. Interactions among the branched-chain amino acids and their effects on methionine utilization in growing pigs: Effects on plasma amino- and ketoacid concentrations and branched-chain keto-acid dehydrogenase activity. British Journal of Nutrition 2000;83:49-58.

Peganova S, Eder K. Studies on requirement and excess of isoleucine in laying hens. Poultry Science 2002;81:1714-1721.

Peganova S, Eder K. Interactions of various supplies of isoleucine, valine, leucine and tryptophan on the performance of laying hens. Poultry Science 2003;82:100-105.

Ribeiro CLN. Proteína bruta, relações aminoacídicas e lisina digestível em dietas para codornas de corte de 15 a 35 dias de idade [tese]. Viçosa (MG): Universidade Federal de Viçosa; 2015.

Rostagno HS, Albino LFT, Donzele JL, Gomes PC, Oliveira RF, Lopes DC, et al. Tabelas brasileiras para aves e suínos: composição de alimentos e exigências nutricionais. 2nd ed. Viçosa: Editora UFV; 2005.

Silva JHV, Costa FGP. Tabelas para codornas japonesas e europeias: tópicos especiais, composição de alimentos e exigências nutricionais. 2.ed Jaboticabal: Funep; 2009.

Universidade Federal de Viçosa. SAEG - sistema de análises estatísticas e genéticas. Viçosa; 2000 